\title{
KESESUAIAN PEMBELAJARAN EKONOMI ISLAM DI PERGURUAN TINGGI DENGAN KEBUTUHAN SDM PADA INDUSTRI KEUANGAN SYARIAH DI INDONESIA
}

\author{
Euis Amalia dan M. Nur Rianto Al Arif \\ Dosen Fakultas Syariah dan Hukum Universitas Islam Negeri (UIN) \\ Syarif Hidayatullah Jakarta \\ euisamalia@yahoo.com, hakam_alarif@yaboo.com
}

\begin{abstract}
This study aims to analyze the potencies and roles of Universities both Islamic Higher Education (PTA) and Public Higher Education (PTU) in providing human resources through Islamic economic and finance learning development that accommodates the competencies of industries demand. The methods used in this study are the path analysis and the content analysis. Based on the Path analysis, it is found that there is a significant relationship between the academicians' perception on the curriculum and learning model, and practitioners'perception on buman resource competencies for industries. In addition, the Paired T Test proves that there is no profile difference between the graduates of PTA and PTU; both have equal opportunities to meet the human resource demand of industries. Meanwhile, based on the content analysis toward the curriculum it is found that the learning system results in different competencies.
\end{abstract}

Keywords: HumanResource, Curriculum, Competency, Path Analysis, Content Analysis.

\begin{abstract}
Abstrak
Studi ini bertujuan untuk menganalisis potensi dan peranan perguruan tinggi agama Islam dan perguruan tinggi umum dalam penyediaan sumber daya manusia yang mengakomodasi kebutuhan industri keuangan syariab. Metode yang digunakan adalah analisis jalur dan analisis isi untuk menjelaskan hubungan antara persepsi akademisi dan praktisi. Berdasarkan analisis jalur, ditemukan bahwa terdapat bubungan yang signifikan antara persepsi akademisi terkait kurikulum dan model pembelajaran dengan persepsi praktisi mengenai kompetensi sumber daya manusia untuk industri. Selain itu, uji $t$ membuktikan tidak ada perbedaan antara lulusan perguruan tinggi agama Islam dan perguruan tinggi umum, keduanya memiliki peluang yang sama untuk memenubi keutuhan sumber daya manusia di industri keuangan syariah. Sedangkan, berdasarkan analisis isi terbadap kurikulum ditemukan babwa perbedaan sistem pembelajaran dan kurikulum yang beragam berdampakpada perbedaan kompetensi yang dihasilkan.
\end{abstract}

Kata kunci: Sumber Daya Manusia, Kurikulum, Kompetensi, Analisis Jalur, Analisis Isi 


\section{Pendahuluan}

Konsep perbankan dan keuangan Islam yang pada mulanya hanya merupakan diskusi teoritis, kini telah menjadi realitas faktual yang tumbuh dan berkembang. Bahkan, saat ini industri perbankan syariah telah bertransformasi dari hanya sekedar bank alternatif dengan sistem syariah menjadi bank yang mampu memainkan peranannya dalam percaturan ekonomi dunia. Perbankan dan institusi keuangan syariah terus mengalami perkembangan yang signifikan. Menurut laporan tahunan Islamic Development Bank (IDB), diperkirakan industri ini tumbuh lebih dari 15 persen per tahun dengan jumlah institusi keuangan syariah lebih dari 300 tersebar di lebih 75 negara dengan perkiraan total aset 500 miliar dolar atau sekitar Rp 4.600 triliun. Dengan kata lain, pasar yang sekarang sudah dicapai baru sekitar 10 persen. Ini berarti industri ini masih menjanjikan perkembangan yang luar biasa di masa depan.

Perbankan syariah berkembang cukup signifikan, sekaligus masih dihadapkan pada berbagai tantangan. Menurut Yuslam Fauzi (2005) setidaknya tantangan yang harus dihadapi perbankan syariah antara lain: 1) customers: perubahan konsumen dari "religion oriented" ke "return oriented" dengan ekspektasi yang sama dengan nasabah konvensional; 2) cakupan wilayah/network dan teknologi informasi masih terbatas; 3) kesulitan memperoleh debitur yang baik; 4) resiko usaha sektor riil masih tinggi, kesulitan mencari debitur yang bankable; 5) persaingan pricing yang semakin tajam (tidak hanya antar bank syariah tetapi juga bank konvensional dan potensi langsung masuk ke pasar modal; 6) keterbatasan rasio Kecukupan Modal (CAR) dengan adanya kebijakan Arsitektur Perbankan Indonesia, bank syariah harus memperkuat modal; 7) keterbatasan kompetensi sumber daya insani (man power).

Khusus untuk masalah sumber daya insani, berdasarkan riset yang dilakukan oleh Universitas Indonesia tahun 2003 diungkapkan bahwa lebih dari 90\% SDM bank syariah saat ini tidak memiliki latar belakang pendidikan ekonomi syariah. Di samping itu, berdasarkan penyampaian Outlook Perbankan Syariab tahun 2007 diketahui bahwa di antara kendala percepatan market share (5\%) perbankan syariah karena faktor SDM, baik di sisi minimnya jumlah SDM 
perbankan syariah maupun kualitasnya yang masih rendah. Menurut Wahyu Dwi Agung (mantan Ketua Asbisindo) dan Syakir Sula, saat ini baru 10\% saja SDI yang memiliki latar belakang syariah yang bekerja di industri keuangan syariah dan yang 90\% adalah berlatar belakang dari konvensional yang dikarbit melalui pelatihan singkat perbankan syariah. Hal ini juga diperkuat dengan adanya penelitian yang dilakukan oleh Universitas Indonesia tentang SDI pada bank syariah. Menurut Harisman (Direktur Direktorat Perbankan Syariah BI, dalam 4-5 tahun ke depan dibutuhkan 10 ribu SDI untuk mengisi industri perbankan syariah di Indoensia. Data BI menyebutkan lebih tinggi lagi, yakni sekitar 14 ribu.

Menurut Mustafa Edwin Nasution (Mantan Ketua Umum IAEI) baru sekitar 20-an universitas yang mengambil peran ini. Itupun hanya 1000-an orang yang berhasil diluluskan setiap tahunnya. Suroso Imam Zadjuli (Guru Besar Universitas Airlangga) mengkalkulasi bahwa dalam jangka menengah antara lima sampai sepuluh tahun mendatang diperlukan sebanyak 38.940 orang lulusan D3 dan Doktor bidang Ekonomi Islam. Sementara dalam jangka panjang antara 10 dampai 30 tahun SDI yang diperlukan adalah 125.790 orang dari lulusan D3 hingga doktor. Selanjutnya dikatakan bahwa untuk memenuhi kebutuhan doktor, minimal 10 perguruan tinggi yang harus membuka program doktor ilmu ekonomi Islam.

Penyiapan SDM-SDM yang handal di bidang keuangan syariah baik untuk industri perbankan syariah maupun industri keuangan syariah lainnya dibutuhkan kerjasama dari berbagai pihak. Jika diperhatikan data yang dikeluarkan oleh bank Indonesia di bawah ini, terlihat masih terjadi kesenjangan antara Perguruan Tinggi Agama Islam (PTAI) dan Perguruan Tinggi Umum (PTU) dalam melakukan pembelajaran ekonomi Islam sehingga lulusan yang masuk di Industri keuangan syariah masih didominasi oleh mereka yang berlatar belakang konvensional. 
Tabel 1.

Latar Belakang Pendidikan Para Pegawai Bank Syariah (dalam persentase)

\begin{tabular}{cccccccccc}
\hline \multirow{2}{*}{ Thn } & \multirow{2}{*}{ SLTA } & \multirow{2}{*}{ D3 } & $\begin{array}{c}\text { S1 } \\
\text { Ekonomi }\end{array}$ & $\begin{array}{c}\text { S1 } \\
\text { Hukum }\end{array}$ & $\begin{array}{c}\text { Fisip } \\
\text { P'tanian }\end{array}$ & $\begin{array}{c}\text { S1 } \\
\text { Teknik }\end{array}$ & $\begin{array}{c}\text { S1 } \\
\text { Syariah }\end{array}$ & \multirow{2}{*}{ S2 } \\
\hline 2009 & 6,2 & 18,7 & 38,0 & 6,2 & 5,2 & 4,9 & 7,6 & 9,1 & 4,1 \\
2008 & 5,3 & 12,1 & 39,1 & 7,2 & 6,8 & 6,3 & 9,2 & 8,6 & 5,3 \\
\hline
\end{tabular}

Sumber: Data Statistik Perbankan Syariah Bank Indonesia, 2010

Berdasarkan pemaparan di atas, maka fokus utama permasalahan dalam penelitian ini adalah "Bagaimana peta potensi pendidikan ekonomi Islam yang diterapkan di Perguruan Tinggi Agama Islam dan Perguruan Tinggi Umum dalam menyiapkan SDM yang dibutubkan oleb Industri Keuangan Syariab di Indonesia". Lebih lanjut penelitian ini bertujuan mendeskripsikan peta pendidikan Ekonomi Islam di Perguruan Tinggi Agama Islam (PTAI) dan Perguruan Tinggi Umum (PTU), menjelaskan persepsi pemangku kepentingan PTAI dan PTU tentang pembelajaran ekonomi Islam di perguruan tinggi masing-masing, menjelaskan persepsi pelaku Industri tentang kompetensi lulusan perguruan tinggi dan profil SDM yang diperlukan, menganalisis pembelajaran ekonomi Islam di PTAI dan PTU terutama dari aspek kurikulum dan metode pembelajaran, menganalisis permasalahan yang dihadapi oleh Perguruan Tinggi maupun industri dalam menghasilkan sumber daya manusia (SDM) serta merumuskan strategi yang tepat dalam menghasilkan kompetensi SDM yang memenuhi kebutuhan pengembangan Industri Keuangan Syariah di Indonesia.

\section{Landasan Teori dan Review Penelitian Terdahulu}

Kurikulum adalah seperangkat rencana dan pengaturan yang mengenai tujuan, isi dan bahan pelajaran serta cara-cara yang digunakan sebagai pedoman penyelenggaraan kegiatan pembelajaran untuk mencapai tujuan pendidikan tertentu (Tim Pekerti-AA PPSP LPP UNS, 2007:8). Kurikulum bukan sekedar daftar matakuliah yang dijabarkan ke dalam silabus yang dapat diambil langsung dari daftar isi buku. Kurikulum seyogyanya mencakup filosofi (visi dan misi), tujuan pendidikan dan kandungan program studi. Kurikulum juga 
harus memuat dampak yang direncanakan dari hasil pembelajaran, yang berupa kompetensi, untuk masa kini dan masa yang akan datang.

Cara yang sederhana untuk mempertimbangkan kurikulum ialah melihat kurikulum itu dari 4 (empat) fase, yaitu isi (content), metode, tujuan (purpose), dan evaluasi. Kurikulum-sebagai suatu keseluruhan-memiliki komponen-komponen yang saling berkaitan, yakni (1) tujuan, (2) materi, (3) metode, (4) organisasi, dan (5) evaluasi. Kurikulum mengemban peranan yang sangat penting bagi pendidikan peserta didik. Setidaknya terdapat 3 (tiga) macam peranan kurikulum yang dinilai sangat penting, yaitu (1) peranan konservatif, (2) peranan kritis-evaluatif, dan (3) peranan kreatif. Ketiga peranan ini sama pentingnya dan perlu diterapkan secara seimbang (Hamalik, 2006: 92-95).

Terdapat 4 (empat) jenis kurikulum, yaitu (1) the bidden curriculum, (2) the actual curriculum, (3) a whole curriculum, dan (4) the public curriculum (Hamalik, 2006: 94). Terdapat 3 (tiga) sumber yang mendasari perumusan tujuan kurikulum, yaitu (1) sumber empiris, (2) sumber filosofis, dan (3) sumber bahan pembelajaran. Sumber empiris, yakni yang berkaitan dengan (a) tuntutan kehidupan masa kini, dan (b) karakteristik peserta didik yang berkembang secara dinamis dan memiliki kebutuhan fisik dan sosial, dan keutuhan pribadi.

Dalam model pembelajaran kreatif, ada upaya mengorganisasikan isi ajaran dan kegiatan belajar sehingga terjadi belajar aktif. Belajar aktif meliputi, di antaranya, (1) belajar menemukan (discovery learning); (2) belajar berbasis masalah (problem-based learning); (3) belajar kontekstual (contextual learning); (4) belajar mandiri (independent learning); (5) belajar kooperatif (cooperative learning); dan (6) belajar pemetaan konsep (concept-mapping learning) (Miarso, 2006).

Beberapa penelitian telah dilakukan terkait kuikulum maupun pendidikan ekonomi dan keuangan Islam. Penelitian yang cukup awal dilakukan oleh Muhammad Aslam Haneef (1995), seorang pemikir ekonomi Islam dari Malaysia yang telah melakukan penelitian terhadap beberapa literatur ekonomi Islam 
dari para pemikir kontemporer besar dengan metode analisis komparatif. Dia memetakan bahwa pemikiran ekonomi Islam setidaknya pda 3 kelompok kategori yaitu: (1) Pendekatan normatif dan legalistik yaitu para ahli dan sarjana di bidang fiqh (Hukum Islam); (2) kelompok medernis yang melakukan upaya interpretasi terhadap ajaran Islam dan berusaha untuk menjawab berbagai persoalan ekonomi yang dihadapi masayrakat saat ini, and (3) para praktisi yang beralatar belakang ekonomi muslim yang mencoba menggabungkan anatra pendekatan fiqh dan ekonomi secara integrasi untuk dapat mengkonstruksi sistem ekonomi Islam dengan mereduksi nilai-nilai yang tidak sejalan dengan Islam dan memberikan pengayaan analisis ekonomi dengan nilai-nilai Islam.

Rifki Ismal (2012) telah mengelaborasi tentang studi pendidikan ekonomi dan keuangan Islam di Inggris. Tulisannya merupakan survey awal berdasarkan pengalamannya kuliah di Durham University sehingga dapat diklasifikasikan beberapa perguruan tinggi yang telah menawarkan pendidikan ekonomi dan keuangan Islam di United Kingdom (UK) dari semua level. Studi ini kemudian didukung oleh hasil penelitian (Ahmede 2008) yang melakukan survey terkait peluang pengembangan bank Islam sejak umat Islam menerima produk bank Islam dan menekankan pentingnya pendidikan publik untuk memberikan pemahaman terhadap hal ini.

Sementara itu juga Rahmatina al Kasyrie (2008) telah melakukan kajian yang relevan berupa studi comparative pada program pendidikan Keuangan Islam khususnya program MBA di beberapa universitas di wilayah Asia, Timur Tengah, dan negara Eropa. Dia menyimpulkan bahwa dosen, pengajaran dan metode evaluasi memainkan peranan yang siginifikan dalam mendukung pengetahuan dan pemahama mahasiswa tentang ekonomi dan keuangan Islam. Serupa dengan penelitian ini juga telah dilakukan oleh Muqarrabin (2010) yang meneliti tentang kurikulum dan silabus Ekonomi Islam di semua perguruan tinggi di lingkungan Muhammadiyah dengan metode content analysis. Pada dasarnya studi ini merekomendasikan pendekatan kurikulum integratif yang dapat diterapakan di semua perguruan tinggi. 


\section{Metode Penelitian}

Pendekatan yang dilakukan dalam penelitian ini adalah kuantitatif dan kualitatif. Teknik analisis kuantitatif yang dipergunakan adalah analisis jalur (path analysis). Sementara teknik analisis kualitatif yang dipergunakan adalah analisis isi (content analysis).

\section{Analisis Jalur}

Telaah statistika menyatakan bahwa untuk tujuan peramalan/ pendugaan nilai $\mathrm{Y}$ atas dasar nilai-nilai $\mathrm{X}_{1}, \mathrm{X}_{2}, \ldots, \mathrm{X}_{\mathrm{i}}$, pola hubungan yang sesuai adalah pola hubungan yang mengikuti Model Regresi, sedangkan untuk menganalisis pola hubungan kausal antar variabel dengan tujuan untuk mengetahui pengaruh langsung dan tidak langsung, secara serempak atau mandiri beberapa variabel penyebab terhadap sebuah variabel akibat, maka pola yang tepat adalah Model Analisis Jalur. Adapun persamaan yang digunakan dalam penelitian ini adalah:

$$
\mathrm{Y}=\mathrm{B}_{0}+\mathrm{B}_{1} \mathrm{X}_{1}+\mathrm{B}_{2} \mathrm{X}_{2}+\text { error }
$$

Dimana:

Y adalah persepsi industri tentang kompetensi SDM

$\mathrm{X}_{1}$ adalah persepsi perguruan tinggi tentang kurikulum

$\mathrm{X}_{2}$ adalah persepsi perguruan tinggi tentang model pembelajaran

Langkah kerja yang dilakukan untuk menghitung koefisien jalur adalah:

a. Gambarkan dengan jelas diagram jalur yang mencerminkan proposisi hipotetik yang diajukan, lengkap dengan persamaan struktural. Harus bisa menterjemahkan hipotesis penelitian yang diajukan ke dalam diagram jalur, sehingga tampak jelas variabel apa saja yang merupakan variabel eksogenus dan apa yang menjadi variabel endogenusnya.

b. Menghitung matriks korelasi antar variabel.

Formula untuk menghitung koefisen korelasi yang dicari adalah menggunakan Product Moment Coefficient dari Karl Pearson.

c. Identifikasikan sub-struktur dan persamaan yang akan dihitung koefisien jalurnya. Misalkan saja dalam sub-struktur yang telah 
kita identifikasi terdapat k buah variabel eksogenus, dan sebuah (selalu hanya sebuah) variabel endogenus $\mathrm{X}_{\mathrm{u}}$ yang dinyatakan oleh persamaan :

$$
\mathrm{X}_{\mathrm{u}}=\mathrm{p}_{x_{u} x_{1}} \mathrm{x}_{1}+\mathrm{p}_{x_{u} x_{2}} \mathrm{x}_{2}+\ldots+\mathrm{p}_{x_{u} x_{k}} \mathrm{x}_{\mathrm{k}}+\varepsilon .
$$

Kemudian hitung matriks korelasi antar variabel eksogenus yang menyusun sub-struktur tersebut.

d. Menghitung matriks invers korelasi variabel eksogenus

e. Menghitung semua koefisien jalur $\mathrm{p}_{x_{u} x_{i}}$, dimana $\mathrm{i}=1,2, \ldots \mathrm{k}$; Menguji kebermaknaan (test of significance) setiap koefisien jalur yang telah dihitung, baik secara sendiri-sendiri maupun secara bersama-sama, serta menguji perbedaan besarnya pengaruh masing-masing variabel eksogenus terhadap variabel endogenus.

\section{Analisis Isi}

Metode analisis isi (content analysis) merupakan suatu metode yang amat efisien untuk menginvestigasi isi media baik yang tercetak maupun media dalam bentuk broadcast. Metode analisis isi (content analysis) pada dasarnya merupakan suatu teknik sistematik untuk menganalisis isi pesan dan mengolah pesan, atau suatu alat untuk mengobservasi dan menganalisis isi perilaku komunikasi yang terbuka dari komunikator yang dipilih. Analisis isi (content analysis) adalah teknik penelitian untuk membuat inferensi-inferensi yang dapat ditiru (replicable), dan sahih data dengan memperhatikan konteksnya.

Analisis isi (Content Analysis) secara sederhana diartikan sebagai metode untuk mengumpulkan dan menganalisis muatan dari sebuah "teks". Teks dapat berupa kata-kata, makna gambar, simbol, gagasan, tema dan bermacam bentuk pesan yang dapat dikomunikasikan. Analisis isi berusaha memahami data bukan sebagai kumpulan peristiwa fisik, tetapi sebagai gejala simbolik untuk mengungkap makna yang terkadang dalam sebuah teks, dan memperoleh pemahaman terhadap pesan yang direpresentasikan (Bell: 2001, h. 13). Penelitian analisis isi berusaha melihat konsistensi makna dalam sebuah teks. 


\section{Analisis}

Analisis Jalur

Tabel: 1

\section{Analisis Jalur}

\begin{tabular}{lcccc}
\hline \multicolumn{1}{c}{ Hubungan } & $\begin{array}{c}\text { Koefisien } \\
\text { Korelasi }\end{array}$ & Kategori Probabilitas & Kesimpulan \\
\hline $\begin{array}{l}\text { Kompetensi Industri }(\mathrm{Y}) \text { dengan } \\
\text { Kurikulum }\left(\mathrm{X}_{1}\right)\left(\mathrm{r}_{\mathrm{yx} 1}\right)\end{array}$ & 0,759 & Erat & 0,000 & Signifikan \\
$\begin{array}{l}\text { Kompetensi Industri }(\mathrm{Y}) \text { dengan } \\
\text { Metode Pembelajaran }\left(\mathrm{X}_{2}\right)\left(\mathrm{r}_{\mathrm{yx} 2}\right)\end{array}$ & 0,739 & Erat & 0,000 & Signifikan \\
$\begin{array}{l}\text { Kurikulum }\left(\mathrm{X}_{1}\right) \text { dengan Metode } \\
\text { Pembelajaran }\left(\mathrm{X}_{2}\right)\left(\mathrm{r}_{\mathrm{x} 1 \mathrm{x} 2}\right)\end{array}$ & 0,510 & $\begin{array}{c}\text { Cukup } \\
\text { Erat }\end{array}$ & 0,005 & Signifikan \\
\hline
\end{tabular}

Sumber: Data terolah

Berdasarkan hasil pengujian di atas, diketahui bahwa untuk semua hubungan variabel memiliki hubungan yang signifikan yaitu antara Kompetensi Industri (Y) dengan Kurikulum ( $\mathrm{X}_{1}$ ), Kompetensi Industri $(\mathrm{Y})$ dengan Metode Pembelajaran $\left(\mathrm{X}_{2}\right)$ dan Kurikulum $\left(\mathrm{X}_{1}\right)$ dengan Metode Pembelajaran $\left(\mathrm{X}_{2}\right)$.

Tabel: 2

\section{Pengujian Individual}

\begin{tabular}{cccccc}
\hline No & Hipotesis & Koefisien jalur & thitung & $\mathrm{t}$ tabel & Kesimpulan \\
\hline 1 & $\rho_{y x 1} \neq 0$ & $\rho_{y x 1}=0,517$ & 4,479 & 2,05 & Ho ditolak \\
2 & $\rho_{y x 2} \neq 0$ & $\rho_{y \times 2}=0,476$ & 4,127 & 2,05 & Ho ditolak \\
\hline
\end{tabular}

Sumber: Data terolah

Dalam penentuan pengaruh variabel penelitian secara keseluruhan didapat nilai koefisien jalur dari penjumlahan seluruh variabel eksogen terhadap variabel endogen. Jadi, persamaan analisis jalur yang terbentuk adalah sebagai berikut :

$$
\begin{aligned}
& Y=\rho_{y x 1} X_{1}+\rho_{y x 2} X_{2}+\varepsilon \\
& Y=0,517 X_{1}+0,476 X_{2}
\end{aligned}
$$




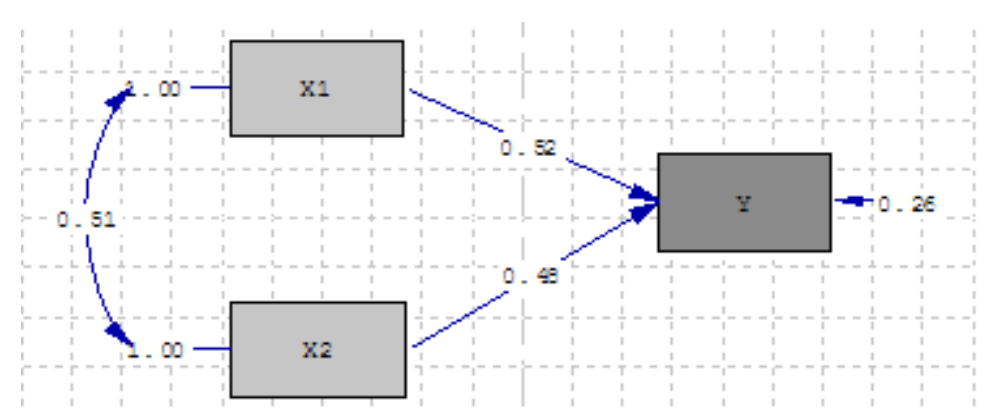

Gambar: 1

\section{Analisis Jalur}

Berdasarkan diagram di atas, dapat diketahui bahwa Kurikulum $\left(\mathrm{X}_{1}\right)$ dan Metode Pembelajaran $\left(\mathrm{X}_{2}\right)$ merupakan dua buah variabel eksogen yang satu dengan yang lainnya mempunyai kaitan korelatif. Selain itu, variabel eksogen tersebut secara bersama-sama $\mathrm{X}_{1}$ dan $\mathrm{X}_{2}$ mempengaruhi variabel endogen Kompetensi Industri $(\mathrm{Y})$.

Tabel: 3

\section{Pengaruh Langsung dan Tidak Langsung Kurikulum $\left(\mathbf{X}_{1}\right)$ Terhadap Kompetensi Industri (Y)}

\begin{tabular}{|c|c|c|c|}
\hline \multicolumn{3}{|c|}{ Pengaruh langsung dan tidak langsung } & \multirow{2}{*}{$\frac{\text { Besar Kontribusi }}{0,267289}$} \\
\hline $\mathrm{X}_{1}$ langsung & pyx $1 \cdot p_{1}$ & $(0,517)(0,517)$ & \\
\hline $\mathrm{X}_{1}$ melalui $\mathrm{X}_{2}$ & $\operatorname{pyx}_{1} \cdot \mathrm{rx}_{1} \mathrm{x}_{2} \cdot \mathrm{pyx}_{2}$ & $(0,517)(0,510)(0,476)$ & 0,125507 \\
\hline \multicolumn{3}{|c|}{ Total pengaruh $\mathrm{X}_{1}$ terhadap $\mathrm{Y}$} & 0,392796 \\
\hline
\end{tabular}

Dari tabel di atas dapat diketahui bahwa pengaruh langsung variable Kurikulum $\left(\mathrm{X}_{1}\right)$ terhadap Kompetensi Industri (Y) adalah sebesar 0,267289 atau 26,7289\% dan pengaruh tidak langsung melalui Metode Pembelajaran $\left(\mathrm{X}_{2}\right)$ adalah 0,125507 atau 12,5507\% sehingga total pengaruh yang diberikan variabel Kurikulum $\left(\mathrm{X}_{1}\right)$ adalah 0,392796 atau sebesar 39,2796\% terhadap Kompetensi Industri (Y). Ini berarti Kurikulum memiliki pengaruh yang cukup besar terhadap Kompetensi Industri. 
Tabel: 4

\section{Pengaruh Langsung dan Tidak Langsung Metode Pembelajaran $\left(\mathbf{X}_{2}\right)$}

(Terhadap Kompetensi Industri (Y

\begin{tabular}{|c|c|c|c|}
\hline \multicolumn{3}{|c|}{ Pengaruh langsung dan tidak langsung } & Besar Kontribusi \\
\hline $\mathrm{X}_{2}$ langsung & pyx2.pyx 2 & $(0,476)(0,476)$ & 0,226576 \\
\hline $\mathrm{X}_{2}$ melalui $\mathrm{X}_{1}$ & $\operatorname{pyx}_{2} \cdot \mathrm{rx}_{2} \mathrm{x}_{1} \cdot \mathrm{pyx}_{1}$ & $(0476)(0,510)(0,517)$ & 0,125507 \\
\hline \multicolumn{3}{|c|}{ Total pengaruh $\mathrm{X}_{2}$ terhadap $\mathrm{Y}$} & 0,352083 \\
\hline
\end{tabular}

Sumber: Data terolah

Dari tabel di atas dapat diketahui bahwa pengaruh langsung variabel Metode Pembelajaran $\left(\mathrm{X}_{2}\right)$ terhadap Kompetensi Industri (Y) adalah sebesar 0,226576 atau 22,6576\% dan pengaruh tidak langsung melalui Kurikulum $\left(\mathrm{X}_{1}\right)$ adalah 0,125507 atau 12,5507\% sehingga total pengaruh yang diberikan variabel Metode Pembelajaran $\left(\mathrm{X}_{2}\right)$ adalah 0,352083 atau sebesar 35,2083\% terhadap Kompetensi Industri (Y). Ini berarti Metode Pembelajaran memiliki pengaruh yang cukup besar terhadap Kompetensi Industri.

Pengaruh total : $\mathbf{P}_{\mathbf{y x i}}+\sum \mathbf{P}_{\mathbf{y x i}} \mathbf{r}_{\mathbf{x i x j}} \mathbf{P}_{\mathbf{y x j}}$
Pengaruh total $\mathrm{X}_{1}=0,267289+0,125507=0,392796$
Pengaruh total $\mathrm{X}_{2}=0,226576+0,125507=0,352083$
Maka Pengaruh total $\mathrm{X}_{1}, \mathrm{X}_{2}=0,392796+0,352083=0,744879$

Hasil ini mendekati hasil Koefisien Determinasi $\left(\mathrm{R}_{\mathrm{yx} 1 \times 2 \times 4}^{2}\right)$ yaitu sebesar 0,744 Pada tabel Model Summary, didapat 1 model analisis jalur dengan nilai koefisien korelasi parsial (R) sebesar 0,863, nilai koefisien determinasi (R Square) sebesar 0,744 (74.4\%). Nilai R Square sebesar 74,4\%, ini menunjukkan bahwa dengan menggunakan model analisis jalur yang didapatkan dimana variabel eksogen yaitu Kurikulum $\left(\mathrm{X}_{1}\right)$ dan Metode Pembelajaran $\left(\mathrm{X}_{2}\right)$, memiliki pengaruh terhadap variabel Kompetensi Industri (Y) sebesar 74,4\%. Sedangkan sisanya $(100 \%-74,4 \%=25,6 \%)$ adalah kemungkinan terdapat aspek-aspek lain yang memiliki pengaruh terhadap perubahan variabel Kompetensi Industri (Y). 
Dalam pengujiannya digunakan Uji Paired Sampel t-test dengan hipotesis sebagai berikut :

$\mathrm{H}_{0}: \mu 1=\mu 2$; Tidak ada perbedaan persepsi dari industri antara profil lulusan perguruan tinggi umum dengan perguruan tinggi Islam

$\mathrm{H}_{1}: \mu 1 \neq \mu 2$; Terdapat perbedaan persepsi dari industri antara profil lulusan perguruan tinggi umum dengan perguruan tinggi Islam

Tabel: 5

\section{Deskripsi Data Profil 1}

\begin{tabular}{cccccc}
\hline & Mean & N & $\begin{array}{c}\text { Std. } \\
\text { Deviation }\end{array}$ & $\begin{array}{c}\text { Std. Error } \\
\text { Mean }\end{array}$ \\
\hline Pair 1 & Lulusan Perguruan Tinggi Umum & 19,0000 & 31 & 3,04412 & 0,54674 \\
\hline & Lulusan Perguruan Tinggi Islam & 19,2258 & 31 & 3,18025 & 0,57119 \\
\hline
\end{tabular}

Sumber: Data terolah

Dari tabel di atas dapat dijelaskan untuk skor lulusan perguruan tinggi umum memiliki rata-rata sebesar 19,00 sedangkan skor lulusan perguruan tinggi Islam didapat rata-rata sebesar 19,2258 .

Tabel: 6

\section{Deskripsi Data Profil 2}

\begin{tabular}{|c|c|c|c|c|c|c|c|}
\hline & \multicolumn{3}{|c|}{ Paired Differences } & \multirow[b]{2}{*}{$\mathrm{T}$} & \multirow[b]{2}{*}{ df } & \multirow[b]{2}{*}{$\begin{array}{c}\text { Sig. } \\
\text { (2-tailed) }\end{array}$} \\
\hline & & Mean & $\begin{array}{c}\text { Std. } \\
\text { Deviation }\end{array}$ & $\begin{array}{l}\text { Std. Error } \\
\text { Mean }\end{array}$ & & & \\
\hline Pair 1 & $\begin{array}{l}\text { Lulusan Perguruan Tinggi } \\
\text { Umum - Lulusan Perguruan } \\
\text { Tinggi Islam }\end{array}$ & -.22581 & 3.58431 & .64376 & -.351 & 30 & .728 \\
\hline
\end{tabular}

Sumber: Data terolah

Pengambilan keputusan didasarkan atas dua metode:

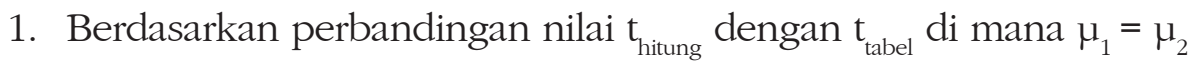
Jika $\left|t_{\text {hitung }}\right|>t_{\text {tabel}}$, maka $\mathrm{H}_{0}$ ditolak Jika $\left|\mathrm{t}_{\text {hitung }}\right|<\mathrm{t}_{\text {tabel }}$, maka $\mathrm{H}_{1}$ diterima

2. Berdasarkan nilai probabilitas dengan $\square=0,05$

Jika probabilitas $>0,05$, maka $\mathrm{H}_{0}$ diterima Jika probabilitas $<0,05$, maka $\mathrm{H}_{0}$ ditolak 
Dari hasil pengolahan SPSS, diperoleh nilai $t_{\text {hitung }}$ sebesar $\mathbf{- 0 , 3 5 1}$ dimutlakkan menjadi $\mathbf{0 , 3 5 1}$. Sedang $t_{\text {tabel }}$ bisa didapat pada tabel t-test, dengan $\alpha=0,05$, karena digunakan hipotesis dua arah, ketika mencari $\mathrm{t}_{\text {tabel }}$, nilai $\alpha$ dibagi dua menjadi 0,025 , dan $\mathrm{df}=30$ (didapat dari rumus $\mathrm{n}-1$, dimana $\mathrm{n}$ adalah jumlah data, 31-1=30). Didapat $t_{\text {tabel }}$ adalah 2,04.

Oleh karena $\mathrm{t}_{\text {hitung }}<\mathrm{t}_{\text {tabel }},(\mathbf{0 . 3 5 1}<\mathbf{2 . 0 4})$, maka $\mathrm{H}_{\mathbf{0}}$ diterima, sehingga dapat disimpulkan bahwa tidak terdapat perbedaaan persepsi industri terhadap profil lulusan apakah berasal dari perguruan tinggi umum ataukah dari perguruan tinggi Islam. Atau jika dilihat dengan menggunakan nilai signifikansi, diketahui bahwa nilai sig $(0,728>0,05)$ sehingga memiliki kesimpulan yang sama dengan Uji t yaitu tidak terdapat perbedaaan persepsi industri terhadap profil lulusan baik berasal dari perguruan tinggi umum maupun perguruan tinggi Islam.

Pada dasarnya, skor persepsi industri terhadap profil lulusan perguruan tinggi umum dan perguruan tinggi Islam memiliki perbedaan yaitu sebesar 0,22581, hanya saja perbedaan tersebut belum cukup signifikan untuk menyimpulkan kalau lulusan perguruan tinggi umum dengan perguruan tinggi Islam berbeda/ Oleh karena itu secara statistik disimpulkan bahwa profil lulusan perguruan tinggi umum dengan perguruan tinggi Islam dianggap memiliki karakteristik yang sama di mata industri.

\section{Analisis Isi}

Dalam sistem pendidikan ekonomi Islam integratif, muatan kurikulum perlu menggambarkan sasaran-sasaran yang hendak dicapai. Ini meliputi (a) penguasaan bahasa Arab dan bahasa Inggris; (b) penguasaan ilmu-ilmu dasar kesyariahan; (c) penguasaan ilmu ekonomi umum; (d) penguasaan ilmu ekonomi Islam; dan (e) penguasaan metodologi penelitian. Sumber daya manusia merupakan salah satu faktor yang memegang peran strategis dalam pengembangan ekonomi Islam, termasuk di dalamnya pengembangan industri keuangan syariah. Akan tetapi sampai saat ini, secara keilmuan ekonomi Islam masih mencari bentuk yang kokoh termasuk dalam pengembangan dan pembentukan sumber daya manusianya. 
Dari sisi kelembagaan, Perguruan Tinggi Agama Islam (PTAI) memperlihatkan 2 (dua) trend kelembagaan pendidikan ekonomi Islam. Pertama, pembentukan jurusan/program studi/ konsentrasi yang mengusung secara spesifik nomenklatur ekonomi Islam/ ekonomi Syariah. Kedua, pembentukan perguruan tinggi (sekolah tinggi) yang mengkhususkan diri pada studi ekonomi Islam/ ekonomi Syariah. Pada trend pertama, selain adanya perbedaan nomenklatur jurusan/program studi/konsentrasi, terdapat pula variasi nomenklatur fakultas yang menaungi jurusan/program studi/ konsentrasi tersebut. Dalam hal ini, terdapat 3 (tiga) nomenklatur fakultas, yaitu (1) Fakultas Syariah, (2) Fakultas Syariah dan Hukum atau Fakultas Syariah dan Ilmu Hukum, dan (3) Fakultas Ekonomi atau Fakultas Ekonomi dan Bisnis.

Di PTAI yang menggunakan nomenklatur Fakultas Syariah, pendidikan ekonomi Islam diselenggarakan oleh Jurusan/ Program Studi/ Konsentrasi yang nomenklaturnya saling berbeda antara satu dan yang lainnya. Dalam hal ini, terdapat varian-varian nomenklatur, yaitu: a) Muamalat; b) Muamalat (Ekonomi Islam); c) Muamalat (Hukum Ekonomi Islam); d) Ekonomi Islam; e) Ekonomi Syariah; f) Keuangan Islam; g) Manajemen Keuangan Syariah; h) Hukum Bisnis Syariah; i) Muamalah Ekonomi dan Perbankan Islam.

Dari segi core keilmuan yang menjadi fokus program studi/ konsentrasi, di fakultas dengan nomenklatur Fakultas Syariah, ditemukan adanya kecenderungan pengembangan 2 (dua) core keilmuan, yaitu Hukum Ekonomi Syariah/Bisnis Islam (Syariah) dan ilmu Ekonomi Syariah (Islam). Yang disebut pertama lebih menitikberatkan aspek hukum (Islam) dari entitas ekonomi, sedang yang terakhir lebih memfokuskan aspek teori, doktrin dan konsepsi Islam tentang ekonomi. Oleh karena itu, biasanya pendidikan ekonomi Islam hadir di bawah naungan Program Studi/Jurusan Muamalat (Ekonomi Islam/Syariah) dan Program Studi/Jurusan Muamalat (Hukum Ekonomi Islam/Bisnis Islam/Syariah).

Berdasarkan kuesioner yang telah disebarkan dan masukan yang disampaikan oleh para praktisi maupun akademisi pada focus group discussion untuk kepentingan penelitian ini maka dapat dianalisis akar permasalahan pembelajaran ekonomi Islam di 
perguruan tinggi dan persepsi industri tentang kompetensi lulusan perguruan tinggi yang dihasilkan:

Pertama, tenaga pengajar merupakan salah satu kunci penting pada perguruan tinggi. Perguruan tinggi Agama Islam (PTAI) memiliki keunggulan tenaga pengajar yang handal pada penguasaan aspek ilmu-ilmu kesyariahan, sementara perguruan tinggi umum memiliki kekuatan tenaga pengajar yang handal pada penguasaan aspek ekonomi. Di pihak lain merupakan kelemahan perguruan tinggi yaitu kurang bahkan sulit sekali ketersediaan sumber daya tenaga pengajar integratif yang mampu memadukan antara aspek ilmu syariah dengan aspek ilmu ekonomi.

Kedua, kurikulum dan kompetensi Inti. Hingga saat ini belum ada kebijakan di tingkat nasional dalam hal standarisasi kurikulum inti ekonomi Islam tingkat nasional baik di Kementraian Agama maupun Kementrian Pendidikan Nasional. Acuan terkait penyusunan kurikulum saat ini adalah Kepmendiknas No 045 tahun 2001, dijelaskan bahwa kurikulum disusun oleh kalangan perguruan tinggi sendiri dengan melibatkan stakeholder terkait, terkesan adanya kebebasan dalam kurikulum. Sementara yang dimaksudkan di sini adalah kurikulum inti yang disepakati oleh elemen perguruan tinggi dan asosiasi profesi yang berkompeten di bidang ekonomi Islam menyepakati sejumlah mata kuliah yang wajib diberikan untuk menghasilkan suatu kompetensi utama menjadi Sarjana Ekonomi Islam/Sarjana Ekonomi Syariah.

Sebagai gambaran kompetensi pendukung yang dibutuhkan adalah bahwa industri saat ini membutuhkan SDM yang lebih menguasai operational skill daripada teori. Menurut mereka alumni perguruan tinggi terlalu teoritis dan tidak siap pakai, kurangnya keahlian baik berupa soft skill dan hard skill. Keterampilan untuk berbicara di depan umum, komunikasi, negosiasi dan menjalin hubungan merupakan beberapa keterampilan yang harus dikuasai oleh para lulusan ekonomi Islam. Kemudian hard skill seperti keahlian penguasaan terhadap komputer dan IT, hal ini diperlukan karena sistem operasional pada industri keuangan syariah yang sudah berbasis sistem teknologi informasi. Industri menginginkan lulusan yang siap pakai dan langsung dapat bekerja tanpa harus 
dilakukan pendidikan dan pelatihan serta adaptasi yang terlalu lama sehingga dibutuhkan biaya untuk up grading karyawan baru yang cukup tinggi. Industri keuangan syariah menilai masih terjadi ketidakcocokan atau mis-match antara kurikulum yang disusun oleh perguruan tinggi dengan kebutuhan industri.

Ketiga, struktur akademik posisi kajian Ekonomi Islam. Sebagian perguruan tinggi telah membuka pendidikan Ekonomi Islam dalam bentuk program studi dari jenjang S1 sampai S3, utamanya di perguruan tinggi umum baru berupa konsentrasi atau bahkan hanya berupa mata kuliah pilihan. Trisakti, UNAIR adalah perguruan tinggi umum yang sangat progresif mengembangkan Ekonomi Islam dengan berbagai konsentrasinya. Akan tetapi kebanyakan perguruan tinggi umum saat ini baru menawarkan sebatas mata kuliah atau konsentrasi.

Sementara perguruan tinggi agama sebagian besar telah membuka program studi ekonomi Islam dengan nama dan pemahaman yang berbeda-beda. Ada program studi Muamalat, Ekonomi Islam, Keuangan Syariah, Manajemen Perbankan Syariah dan ada juga nama program studinya Muamalat Ekonomi Perbankan Syariah. Kata Muamalat pun menjadi rancu ketika sebagian memaknainya Ekonomi Syariah dan yang lain memaknainya Hukum Ekonomi Syariah. Perbedaan struktur akademik ini menjadi salah satu kendala dalam memenuhi kebutuhan sumber daya ekonomi Islam sesuai dengan kompetensi yang diharapkan yaitu SDM integratif.

Keempat, sarana praktikum, sistem informasi dan akses referensi Ekonomi Islam masih terbatas. Di beberapa perguruan tinggi umum dan perguruan tinggi agama Islam sarana dan prasarana telah cukup memadai. Ketersediaan akses wi-fi, perpustakaan yang memadai baik secara infrastruktur maupun jumlah koleksi literatur, fasilitas pembelajaran di kelas yang cukup baik, dan laboratorium praktik mahasiswa seperti laboratorium bank mini syariah. Sehingga secara keseluruhan sarana dan prasarana yang memadai ini diharapkan akan mampu berkorelasi positif pada efektivitas kegiatan belajar mengajar ekonomi Islam di perguruan tinggi.

Pada beberapa perguruan tinggi -terutama perguruan tinggi di daerah- masih Salah satu kondisi yang menjadi kendala dalam 
proses pembelajaran juga adalah terbatasnya referensi berupa buku teks maupun jurnal ilmiah khusus bidang kajian Ekonomi Islam. Keterbatasan jaringan sisitem informasi membuat kurangnya akses kepada berbagai jaringan jurnal on-line yang mengakibatkan informasi yang didapat seringkali sudah tidak up to date.

Kelima, kebijakan pimpinan dan kultur akademik. Pada beberapa perguruan tinggi baik perguruan tinggi umum maupun perguruan tinggi agama Islam, perkembangan kajian ekonomi Islam sangat didukung oleh pimpinan. Sebagai contoh di Fakultas Ekonomi Universitas Airlangga kehadiran Departemen Ekonomi Syariah merupakan sebagai bukti dukungan pimpinan pada pengembangan ekonomi Islam. Kemudian di Fakultas Ekonomi Universitas Indonesia, pembelajaran ekonomi Islam yang selama ini hanya menjadi mata kuliah pilihan, saat ini telah membuka program studi atau ekonomi Islam.

Untuk itu, ada beberapa langkah strategis yang dapat dilakukan untuk penyiapan SDM yang unggul dan dapat memenuhi kebutuhan pengemabangan ekonomi dan keuangan syariah di Indonesia antara lain: 1) penguatan Program Studi Ekonomi Syariah dan pengembangan konsentrasinya sesuai dengan perkembangan dan kebutuhan industri dengan kurikulum integratif ditopang oleh sarana prasarana yang memadai; 2) memperbanyak riset, studi, dan penelitian tentang ekonomi Islam, baik yang berskala mikro maupun makro. Hal ini juga untuk mendorong karya ilmiah berupa penerbitan buku dan jurnal ilmiah.;3) Memfasilitasi tenaga pengajar ke jenjang pendidikan yang lebih tinggi untuk peningkatan kualitasnya serta memfasilitasi mereka dalam hal pelatihan, seminar, workshop maupun pendidikan professional di bidang ekonomi dan keuangan Islam baik di dalam maupun di luar negeri; 4) dalam rangka peningkatan dan penjaminan kualitas adalah diperkuat perangkat mutu manajemen, seperti BAN PT, ISO, Sertifikasi Risk Management, Sertfikasi dosen dan program sertifikasi lainnya yang terstandar; 5) perlu dilakukan standarisasi kurikulum ekonomi Islam tingkat nasional dalam hal ini yang merupakan kompetensi inti; 6) salah satu yang menjadi harapan industri keuangan syariah terhadap para lulusan ekonomi Islam adalah SDM "siap pakai" untuk itu perlu adanya program magang maupun on the job training di industri 
keuangan syariah dan praktikum yang memadai; 7) sosialisasi dan edukasi ekonomi syariah sejak dini mulai tingkat SD, SMP, SMU dan kepada komunitas masyarakat umum yang lebih luas dengan metode dan cara yang tepat; 8) mengembangkan networking yang lebih luas dengan berbagai institusi pendidikan ekonomi Islam, lembaga-lembaga keuangan Islam di dalam maupun luar negeri.

Adanya strategi seperti ini akan mendorong percepatan sosialisasi dan implementasi ekonomi Islam di Indonesia.

\section{Kesimpulan}

Berdasarkan penelitian yang dilakukan dapat ditarik beberapa kesimpulan:

Perguruan tinggi di Indonesia memiliki potensi yang besar dalam menyiapkan SDM integratif untuk dapat memenuhi kebutuhan perkembangan industri keuangan syariah. Hanya saja saat ini masih terjadi keragaman struktur akademik dan nomenklatur program studi yang bervariasi sehingga menimbulkan kekaburan terhadap kompetensi lulusan.

Terdapat pengaruh dan hubungan yang signifikan antara persepsi perguruan tinggi tentang kurikulum dan model pembelajaran dengan persepsi industri tentang kompetensi SDM yang dihasilkan.

Secara umum tidak terdapat perbedaan profil lulusan PTAI dan PTU dalam kompetensi yang dimiliki berdasarkan persepsi industri. Dengan kata lain, lulusan dari perguruan tinggi tersebut memiliki peluang yang sama dalam memenuhi kebutuhan industri.

Berbagai perguruan tinggi di Indonesia ini telah berupaya menyiapkan SDM dalam memenuhi kebutuhan industri keuangan syariah dengan pembukaan berbagai program studi, konsentrasi di bidang ekonomi dan keuangan syariah. Namun, fakta menunjukan masih terdapat berbagai kendala yang masih harus dihadapi oleh program studi terutama terkait SDM dosen, sarana prasarana, kurikulum, kultur akademik yang kondusif maupun kebijakan di level pimpinan PT itu sendiri. Untuk hal ini diperlukan beberapa langkah yang sangat strategis bagi upaya penguatan program studi dan penguatan SDM dosen dan peningkatan sarana prasarana pembelajaran yang mendukung. 


\section{Daftar Pustaka}

Ahmed, Salahuddin. 2006. Islamic Banking Finance and Insurance: A Global Overview. Kuala Lumpur: A.S. Noordeen Publishing.

Al Arif, M. Nur Rianto. 2011. Dasar-dasar Ekonomi Islam. Surakarta: Era Intermedia

al Kasrie, Rahmatina. 2010. "Evaluating MBA Program in Islamic Banking and Finance: A Performance-Importance Analysis", The paper has been presented at The 2010 Oxford business and Economic Conference, St. Hugh Cllege, Oxford University, United Kingdom. 28-30 June 2010.

Al-Rasyid, Harun. 2005. Analisis Jalur (Path analysis) sebagai Sarana Statistika dalam Analisis Kausal. Bandung: LP3S FE Unpad.

Amalia, Euis. 2006. Potret Pemikiran, Perkembangan dan Gerakan Ekonomi Islam. Jurnal AHKAM, vol. 8 nomor 1.

------. 2009. Keadilan Distributif dalam Ekonomi Islam: Penguatan Peran LKM dan UKM, Jakarta: Rajagrafindo.

Anonymous. 2009. Menggodok Kurikulum-Menyiapkan SDM Andal, Majalah Sharing Edisi April 2009, Jakarta

Berg, Bruce L. 2001. Qualitative Research Methods for the Social Science $4^{\text {th }}$ ed. Boston: Allyn and Bacon.

Dale, Margaret. 2003. Developing Management Skills: Techniques For Improving Learning = Meningkatkan Ketrampilan Manajemen: Teknik-Teknik Meningkatkan Pembelajaran Dan Kinerja, Jakarta: Bhuana Ilmu Populer

Davis dan Cosenza R. M. 1993. Business Research for Decision Making. Belmont: PWS-KENT Publishing Company

Hamalik, Umar. 2006. Manajemen Pengembangan Kurikulum. Bandung: Remaja Rosda Karya

Haneef, Mohamed Asalam. 1995. Contemporary Islamic Economic Thought: A Selected Comparative Analysis. Kuala Lumpur: S. Abdul Majeed \& Co.

Haron, Sudin. 2001. Islamic Banking Malaysia. Selangor: Darul Ehsan.

------. 2007. Sistem Kewangan dan Perbankan Islam. Kuala Lumpur: Business School.

Idi, Abdullah. 1999. Pengembangan Kurikulum: Teori Dan Praktik. Jakarta: Gaya Media Pratama

Ismal, Rifki. 2012. "Pendidikan Ekonomi dan Keuangan Islam di Inggris", Makalah disampaikan dalam Workshop Arsitektur Ilmu Ekonomi Islam ("The Education of Islamic Economy and Finance in UK a paper presented at the workshop entitled the architecture of Islamic Economics), January 28, 2012. 
Kothari, C.R. 2004. Research Methodology: Methods and Techniques. New Delhi: New Age International Limited Publisher.

Kuncoro, Mudrajad. 2003. Metode Riset: Untuk Bisnis dan Ekonomi. Erlangga. Jakarta.

Levin, Richard \& David S Rubin. 1998. Statistics for Management. Prentice Hall: New York.

Mannan, M Abdul. 1992. Ekonomi Islam: Teori dan Praktik, alih bahasa: Potan Arif Harahap. Intermasa: Jakarta

Metwally, M. M. 1993. Essays on Islamic Economics. Academic Publisher: Calcutta.

Mulyasa, E. 2004. Kurikulum berbasis kompetensi : konsep, karakteristik. Bandung: Rosdakarya

Muqarrobin, Masyhudi. 2010 "The Development of Curriculum and Silaby on Islamic Economics Departement at Mubammadiyyah Universities: An Offering", paper, presented on Islamic Economics Curriculum Workshop at Tazkia College, P3EI UII Jogjakarta and University of Muhammadiyah Forum

Pannen, Paulina. 2001. Konstruktivisme Dalam Pembelajaran. Jakarta: Departemen Pend.\& Kebud

--------. 2001. Mengajar Di Perguruan Tinggi: Konstruktivisme Dalam Pembelajaran. Jakarta: PAU-PPAI,Univ.Terbuka

Pinar, William F. 1995. Understanding Curriculum : An Introduction To The Study. New York: Peter Lang

Riduwan dan Engkos Achmad Kuncoro. 2008. Cara Menggunakan dan Memaknai Analisis Jalur. Bandung: CV Alfabeta.

Saeed, Abdullah. 2003. Bank Islam dan Bunga: Studi Kritis dan Interpretasi Kontemporer tentang Riba dan Bunga terjemahan oleh M. Ufuqul Mubin, dkk. Yogyakarta: Pustaka Pelajar

Sekaran, Uma. 2000. Research Methods for Business: A Skill Building Approach 3rd ed. New York: John Willey \& Sons, Inc

Singh, Yogesh Kumar. 2006. Fundamental of Research Methodology and Statistics. New Delhi: New Age International Limited Publisher

Sukmadinata, Nana Syaodih. 2005. Pengembagan Kurikulum : Teori Dan Praktek, Bandung: Remaja Rosda Karya

Suparman, M. Atwi. 2001. Konsep Dasar Pengembangan Kurikulum. Jakarta: PAU-PPAI-Univ.Terbuka

Sutopo, Hendyat. 1986. Pembinaan Dan Pengembangan Kurikulum : Sebagai Substansi Problem. Jakarta: Bina Aksara

Tim IDB, 2009. 33 ${ }^{\text {rd }}$ IDB Annual Report 1428 H (2007-2008). Jeddah: IDB

Tim LMFE UNPAD. 2007. Laporan Riset Lab Manajemen FE (LMFE) UNPAD bekerja sama dengan Direktorat Perbankan Syariah BI. 